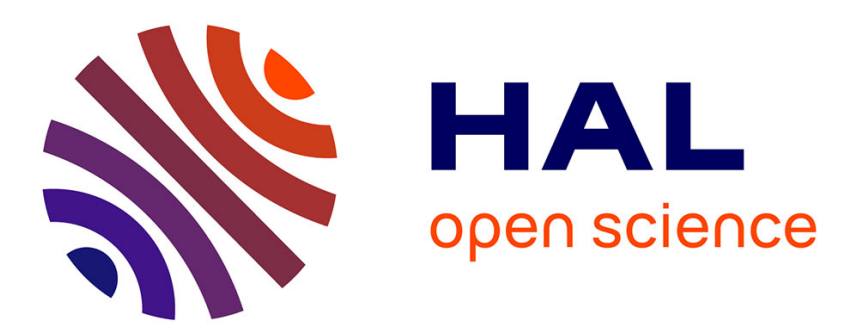

\title{
Social Innovation in Translation: New Welfare Instruments in Turkey
}

Ceren Ark Yildirim, Marc Smyrl

\section{To cite this version:}

Ceren Ark Yildirim, Marc Smyrl. Social Innovation in Translation: New Welfare Instruments in Turkey. SIYASAL: Journal of Political Sciences, 2019, 28 (1), pp.99-115. 10.26650/siyasal.2019.28.1.0010 . halshs-02524527

\section{HAL Id: halshs-02524527 https://shs.hal.science/halshs-02524527}

Submitted on 4 May 2020

HAL is a multi-disciplinary open access archive for the deposit and dissemination of scientific research documents, whether they are published or not. The documents may come from teaching and research institutions in France or abroad, or from public or private research centers.
L'archive ouverte pluridisciplinaire HAL, est destinée au dépôt et à la diffusion de documents scientifiques de niveau recherche, publiés ou non, émanant des établissements d'enseignement et de recherche français ou étrangers, des laboratoires publics ou privés.

\section{(c) (1) $\$$}

Distributed under a Creative Commons Attribution - NonCommerciall 4.0 International 


\title{
Social Innovation in Translation: New Welfare Instruments in Turkey
}

\section{Ceren Ark Yıldırım ${ }^{1}$}

\author{
Marc Smyrl $^{2}$ (1)
}

\begin{abstract}
The concept of social innovation has grown in popularity in policy circles as a remedy both to government and market failure. We can usefully define social innovation as a new approach to meeting social needs by the empowerment of individuals through collaborative actions of governments, private enterprises, and civil society actors. The emergence of this new approach is best explained as a process of translation, by which we mean the movement of concepts across first sectoral and then national boundaries. In this process, imported elements are combined with existing ones to create new policy instruments. We first discuss the development of the social innovation approach through the translation of policy elements from the economic to the social sector. We then illustrate the further translation of policy elements across national borders through two Turkish examples of the use of smart cards to deliver social benefits.
\end{abstract}

\section{Keywords}

Social innovation $\bullet$ Turkey $\bullet$ Policy transfer $\bullet$ Translation $\bullet$ Smart cards

\section{Çevirideki Sosyal Inovasyon: Türkiye'deki Yeni Refah Devleti Politika Aracı}

Öz Yönetim ve piyasa başarısızığına bir çare olarak görülen, sosyal inovasyon politika çevrelerinde giderek popülerlik kazanmaktadır. Sosyal inovasyonu, bireyleri güçlendirerek ve kar getiren işletmelerin ve sivil toplum aktörlerinin katılımı ile sosyal ihtiyacın karşılanabileceğini kabul eden yenilikçi bir yaklaşım olarak tanımlayabiliriz. Bu yeni yaklaşımın ortaya çıkışı, politika çevirisi kavramıyla açıklanabilir. Biz, politika çevirisini (policy translation), kavramların öncelikli olarak sektörel sonra da ulusal sınırlar arasındaki hareketi olarak tanımlamaktayız. Bu süreçte, ithal edilen elemanlar, var olan elemanlar ile birleşip yeni bir politika aracı yaratmaktadır. İlk olarak, sosyal inovasyon yaklaşımının gelişimini, politika unsurların ekonomik sektörden sosyal sektöre çevirisi (translation) aracılığıyla tartışacağız. Daha sonra da, ulusal sınırların ötesine geçen politika unsurların çevirisini sosyal refah yardımları için kullanılan iki akılı kart örneği ile göstereceğiz.

\section{Anahtar Kelimeler}

Sosyal inovasyon • Türkiye • Politika transferi • Politika çevirisi • Akıllı kartlar

1 Corresponding author: Ceren Ark Yıldırım, Istanbul University, Faculty of Political Sciences, Department of Political Science and Public Administration, Istanbul, Turkey. Email: ceren.yildirim@istanbul.edu.tr ORCID: 0000-0003-0227-3822

2 Marc Smyrl, Université de Montpellier, Centre d’Etudes Politique de l'Europe Latine, Montpellier, France. Email: marc.smyrl@umontpellier.fr ORCID: 0000-0003-4399-9101

To cite this article: Ark Yildirim, C., \& Smyrl, M. (2019). Social innovation in translation: New welfare instruments in Turkey. SiYASAL: Journal of Political Sciences, 28(1), 99-115. http://doi.org/10.26650/siyasal.2019.28.1.0010 


\section{Social Innovation in Translation: New Welfare Instruments in Turkey}

"Social innovation" has become a fashionable label for policy in the first decades of the $21^{\text {st }}$ century, taken up - among others - by the European Union and the OECD. The initiatives placed in this category share a number of distinctive features. Most obvious is the central role-played by innovative technologies. Another is the systematic blurring of the lines between public and private; between the state, businesses, and civil society organizations. Both of these are illustrated by the smart cards at the heart of the examples that will be developed in the final section of this article. Beyond this, recurring references to "social enterprise," "social entrepreneurship," and "individual empowerment" mark projects ranging from income support to health improvement as part of an identifiable larger movement.

In some ways, this renewed emphasis on social support is a return to one of the founding principles of economic growth after 1945: social protection is not only complementary to but indispensable for economic production. The neoliberal movement in public philosophy after 1980 called this into question for a generation, bringing back for a time the $19^{\text {th }}$ century notion of the necessary opposition between social support and free enterprise. Since at least the early 2000 s the idea that innovative social policies are compatible with, indeed necessary for, economic growth is once again gaining broad acceptance. This does not imply, however, a return to the principles and practices of the $20^{\text {th }}$ century welfare state. Indeed, a central premise of this article is that these new policies are best understood as critiques of the $20^{\text {th }}$ century welfare model and as the application to social support policies of ideas and instruments whose origins are found in other fields of endeavor, of which the most important are the technological innovation policies of the private sector and a vision of economic progress informed by models of endogenous development.

From this starting point we proceed in three sections. The first develops the notion of translation and grounds it in the literature on policy analysis, arguing in particular that translation provides the most appropriate heuristic for understanding the movement of policy-relevant ideas and instruments across sectoral as well as national boundaries. We then consider the translation across sectors of distinct elements comprising social innovation. A final section turns to translation across national boundaries, taking up the example of the adoption of social innovation in Turkey and in particular of the use of smart cards for income support in two very different settings: at the local level in the low income neighborhoods of Istanbul, and by the Turkish Red Crescent as a means of providing income support to persons displaced by the Syrian conflict. The technological elements of these policy instruments, we demonstrate, are only the most obvious element of a much richer exercise in translation, whose political, social, and economic components are also innovative.

\section{Policy in Translation}

John Kingdon (1984: 77) famously noted that no one really knows where policy ideas originate. In many instances, however, what we seek is not to find the ultimate source of a policy idea but rather to trace the movement of an existing instrument from one setting to another. Discussions of policy convergence center on this question, as do 
claims of transfer and emulation. Not a complete theory of ideas but rather a working heuristic of their movement and adaptation is needed in such situations to organize and characterize our observations and to generate further hypotheses suitable for empirical investigation. Meeting even this more limited theoretical goal has proven problematic, however. In part, this is due to the overreach by and subsequent resistance to the models of convergent development and modernization. Hegemonic in the 1950s and 1960, these were subsequently criticized for their unexamined Western-centered approach and, more broadly, their strongly teleological predisposition. However the movement of policyrelevant ideas should be understood, simply seeing it as the ever-broader application of a North-Atlantic model of development or modernity clearly was not adequate. (De Maillard and Hassenteufel, 2003) The abandonment of development or modernization as analytical concepts has not meant the end of inquiries into convergence, as evidenced by the thriving field of research into policy transfer and learning through Europeanization. (Bache and Jordan, 2006; Holzinger and Knill, 2005; Saurruger and Surel, 2006) Resistance to this notion is evident as well, however. For countries such as Turkey, adopting policy instruments similar to those found in member states of the European Union does not necessarily imply that pressure was applied by the EU or that Turkish authorities explicitly sought convergence. This may be true in some areas such as immigration or competition policies (Aidin and Kirişci, 2013) but not in others such as health policy (Y1lmaz, 2017) The question in each case is an empirical one, and newer normative and teleological terms such as Europeanization are no more helpful in this context than older ones such as development or modernization.

It is in large part to avoid this kind of ambiguity that we turn here to the principal of translation, in the sense developed by Campbell (2004), to understand the movement of ideas and the influence of this movement on the design and use of policy instruments. By translation, Campbell (2004: 80) designates a mechanism in which ideas coming from outside are combined with already existing practices so as to create new instruments or processes. The externality of one or more policy element distinguishes this from the similar, and more general concept of bricolage, the combination of previously distinct elements to create something new. This principle, under various names, is central to the early $20^{\text {th }}$ century institutionalist current of economics, the roots of which are found in the work of Veblen for whom "tool combination" was at the heart of technological innovation. ${ }^{1}$ The insight of new institutionalists such as Campbell has been to apply this same principle to the abstract instruments of public policy.

Critically for the argument we propose here, the novelty of the policy instrument created through translation does not necessarily imply convergence either in intent or in outcome. Campbell's emphasis is rather on the importance of context: “... in order for new instruments to take hold they must be framed with combinations of existing cultural symbols that are consistent with the dominant cognitive and normative institutions, " with the result that "new ideas are combined with already existing institutional practices and therefore are translated into local practices in varying degrees." (Campbell, 2004: 70; 80)

1 The clearest statement of Veblen's thinking on this point is probably the essay 'On the merits of borrowing,' found in the second chapter of his 1915 book Imperial Germany and the Industrial Revolution. The argument is taken up and recast in more conventional academic terms by Ayres (1944: chapter 6). 
Both the origin of "new ideas" and the location of "existing institutional practices" are left ambiguous by Campbell. While the notion of translation clearly applies to the movement of ideas across national boundaries - the usual topic for studies of policy transfer - we suggest that there is good reason to apply it more broadly. In the following sections, we will indeed follow the translation of policy elements across national borders into Turkey, but prior to that we will follow a dynamic of translation across the conceptual borders that separate technology, local development, and social policies. Proceeding in this way has two advantages. In the first place, it allows us to untangle the complex web of definitions that have variously been applied to social innovation and helps to explain the source of this complexity. In addition, mobilizing the same notion to describe transfer across policy sectors and across national boundaries preserves us against any recurrence of teleology; adapting as one element of a response to a unique local situation an instrument pioneered elsewhere does not make that response any less original, nor does it diminish the importance of local context.

\section{Elements of Social Innovation: Translation across Sectoral and Conceptual Borders}

Despite - or perhaps because of - its growing popularity in policy circles, social innovation (hereafter, SI) lacks a robust definition in scientific literature. The term is applied to a heterogeneous set of initiatives and organizations, which range from policy initiatives on the part of traditional public sector agencies to the interventions of voluntary and community organizations. One useful way to approach the problem of definition is by distinguishing the SI model more clearly from its predecessors. Proponents of the approach highlight the contrast between it and bureaucratic command and control, putting forward the prospect of "a more relational, participatory mode of governance and policymaking." (Reynolds et al., 2016: 7) As a starting point, we can usefully define social innovation as a broad category of policies attempting to meet social needs through the empowerment of individuals. SI projects typically seek to provide a service or serve a population that is difficult to reach with existing public instruments. The actors of such projects may include any combination of public, for-profit, and non-profit organizations but typically these will be part of a larger network or cooperative initiative.

The varied initiatives brought together under the heading of SI share a critical approach to welfare state policies that calls into question the centrality of the state bureaucracy both in defining problems and in dispensing solutions, as well as focusing on the emerging social issues of the late $20^{\text {th }}$ century, such as an aging population and the integration of marginalized groups. To this new look at social problems and the sources of solutions to them, have been added elements taken from two fields of economic policy that were initially distinct from each other, as well as from social questions: first the endogenous approach to territorial development and second the models of open and user innovation in information and communications technology (ICT).

\section{From A Critique of The Welfare State to A Market-Based Approach to Social Policy}

A first observation concerning SI initiatives is thus that they are distinct from several other familiar types of policies intended to improve social conditions. Most obviously, 
they do not fit the top-down bureaucratic model associated with the $20^{\text {th }}$ century welfare state in which central direction and national uniformity were seen as necessary to achieving the goals of universality and equality. (Le Grand, 2003) Welfare states as they were established in the 1950s and 1960s were premised on full employment, patriarchal families, and a youthful and expanding population. All of these are now far less prevalent. For the countries of Europe, North America or Japan, an obvious emerging problem is the aging of the population and its consequences for health care and for economies and societies more generally. As the elderly populations grow, both absolutely and proportionally, new ways must be sought both to meet its direct medical and social needs. In a similar vein, economies in which unemployment has become chronic can no longer depend on the workplace as an automatic mechanism of assimilation for socially marginal populations.

In addition to challenges linked to the evolution of social problems, dissatisfaction with welfare state regimes inherited from the $20^{\text {th }}$ century has focused increasingly on their top-down and anti-market nature. Beyond the multiplication of "regimes" identified by Esping-Andersen and his many successors, $20^{\text {th }}$ century welfare states shared two general traits. They sought, albeit to varying degrees, to protect certain activities or social groups from the market through what Esping-Andersen (1990) called "decommodification". In addition, they increased the centrality and responsibility of national governments and their budget as providers of resources for social welfare. The liberal turn not just of economies but of social relations since the 1980s has led to growing dissatisfaction with policies that left little or no place for markets or initiative to citizens. Recipients of social assistance have increasingly manifested the desire to be treated, in the evocative terms of Julian Le Grand (2003), as "queens" and not "pawns," as active consumers or better yet full participants rather than as passive subjects.

The emphasis on empowerment marks the distance between social innovation projects and the prescriptive top-down approach typical of $20^{\text {th }}$ century welfare state bureaucracies. We are very far from the world of the British and Swedish civil servants described in the 1970s by Heclo (1974), who self-consciously sought to establish social policies in the absence of (or at least in advance of) active social demand for them. The consumerist turn of the 1980s and 1990s cast serious doubt on this approach; the recipients of public services are increasingly considered as clients and are expected to take responsibility for their choices. In this way, the smart card based initiatives described in this article's final section differ from older approaches based on the direct distribution of material supplies to low-income or displaced persons by seeking to empower them in the market system, creating economic space in which they can make choices, but also face risk.

At the same time, the SI model can be distinguished from several other critiques of the welfare state. One alternative, present in the UK but emphasized particularly in liberal regimes such as New Zealand, is "social investment," (Morel et al., 2011), which seeks to redeploy public budgets toward proactive investment in fields expected to encourage economic growth and reduce the potential for social problems. Many of these center on the development of human capital, whether through early childhood education or lifelong learning, but they also include active labor market policies and an emphasis on "flexible security" rather than protection of existing jobs or firms. The SI model explored in this 
article is largely compatible with this framework, but depends less on state initiatives and public budgets, while giving additional emphasis to the role of technology and individual enterprise.

For all of its acceptance of the role of the private sector, however, the SI model is also distinct from the mid-twentieth century ethos of "corporate social responsibility," in which successful enterprises were expected to "give back to the community" either through charitable endeavors or through contributing to the funding of welfare state policies such as health insurance and pensions. While the latter model in particular sought to limit the public role by demonstrating the adequacy of private welfare provision (Smyrl, 2014), the social innovation approach takes a more collaborative turn, emphasizing the creation of public-private partnerships.

This approach, finally, diverges from what was long held to be the only viable alternative to bureaucratic or corporate dominance of social intervention: the model of voluntary non-profit organization, whether in the form of NGO's, of religious charities, or of citizens' associations. These are present in the new model whose outlines we seek to discover, but do not act alone. The social innovation approach, as will be detailed below, combines elements of all three of the older models to make something new. The Red Crescent debit card for, example, is premised on cooperation among local, national, and supra national actors from both the public and private sectors.

The liberal influences on this the project can be seen in discussion by sources such as the OECD, which notes that "Social innovation can help to remedy both government and market failure." (OECD, 2016: 12) To speak in terms of market failure implies that the market can, under the right circumstances succeed, including providing social goods. This is very different from the socialist or even the social democratic premise that the market itself is the central problem and that the only just and effective solution to problems of social insurance or inequalities is to replace it when possible. This is the philosophy behind decommodification of basic needs, from which SI marks a clear departure.

The emphasis on financial sustainability (OECD, 2016: 18) marks another important difference with the tax-funded model of social policy, including those focused on "social investment." Ideally, any given project should support itself. (OECD, 2016: 19) Even farther away from the state-led welfare state of the $20^{\text {th }}$ century, but in a direct line with the technological "open innovation" models discussed in the following section, is a positive attitude toward revenue-generating activities and a conviction that expertise in and of itself can be a marketable commodity. That said, however, the distinction with profitcentered enterprise remains central. To the extent that social innovation is contrasted with the practices of business, it is usually by downplaying (although not entirely eliminating) the profit motive (Reynolds, Gabriel, and Heales, 4) Bringing these elements together, one possible definition of social innovation is proposed by Phills, Deiglmeier and Miller (2008) as follows:

A novel solution to a social problem that is more effective, efficient, sustainable, or just than existing solutions and for which the value created accrues primarily to society as a whole rather than private individuals". 


\section{From Economic Innovation to Social Innovation}

To the inadequacies of welfare state regimes evoked in previous section, elements taken from the new dynamic of economic innovation have been proposed as solutions. As such, this is not particularly surprising. It is worth noting, after all, that the structure of $20^{\text {th }}$ century welfare state regimes were themselves deeply influenced - even in the purportedly liberal UK and USA - by the planning-based economic models that prevailed at the time of their consolidation (Smyrl, 2014). Planning was applied to health, employment, and pension policies in the 1940s and 1950s much as it was to industrial production. Two generations later, solutions - this time based on choice and competition - are once again being imported from the economic to the social field. Two of these are of particular importance for understanding the development of the SI model: the practices of open innovation, with origins in the field of technological development, and of endogenous development, whose source can be found in debates on economic geography. We look first to the latter.

Contemporary descriptions of social innovation regularly include references to the EU's cohesion polices. In a 2014 report, the European Commission explicitly called for increased "synergy" among "innovation and competitiveness-related Union programs" on the one hand and the EU's structural and investment funds. (Enabling Synergies, 2014) The structural and investment funds (ESIF) of the EU such as the European Regional Development Fund (ERDF) and the European Social Fund (ESF) are indeed a recurring contributor to social innovation budgets. These elements serve as a reminder that one of the intellectual and institutional threads woven into SI is the "integrated approach" to territorial development put forward by the European Community in the 1980s and 1990s, which itself was strongly influenced by the economic literature on endogenous development.

This endogenous vision of development was defined in the European context largely in opposition to the 'top down' approach identified with national planning schemes and bureaucracies such as the French planning commissariat, the Italian Cassa del Mezzogiorno, or the Department of Environment in the UK. The proponents of endogenous development stressed both local, as opposed to central, decision-making and the mobilization of local resources and ideas, as opposed to depending on transfers from outside. A key element of this approach as seen by the European Commission in the 1980s and 1990s, although one whose implementation proved disappointing, was the direct involvement of non-state economic actors, in particular labor and firms, in a coherent planning process. (Behrens and Smyrl, 1999)

Underlying the emphasis on territory and on endogenous development was a critique of the dominant neo-classical model of economic development that suggested that wealth would naturally spread from the center to the periphery as capital sought higher returns in areas where it was scarce. The critical perspective initially inspired by the work of economist G. Myrdal (1957) raised the prospect of the opposite dynamic: a geographical concentration of capital, and of wealth more generally, if the market was left to itself. Development initiatives bringing together public and private partners who shared a commitment to improving local situations in economically peripheral regions was seen by the European Commission in the 1980s and 1990s as a potentially effective countermeasure, and became a central organizing element of the structural funds (Behrens 
and Smyrl, 1999). A similar logic at the level of member states rather than local regions underlay the European Union's subsequent and ongoing cohesion policies. All of these have in turn provided both intellectual models and sources of institutional financing for contemporary social innovation initiatives.

A second key element of what was to become the SI model was imported from critical economic analysis; this is the approach based on open innovation initially developed by $\mathrm{H}$. Chesbrough (2003). Like theories of endogenous development, open innovation stressed the importance of networks and partnerships, but in this case the initial goal was technological development. The open innovation model posits that knowledge necessary for commercially successful technical innovation can most efficiently be produced not within a single firm but through an open process of information sharing. (Chalmers, 2012: 18)

To Chesbrough's argument about the importance of an innovation system that makes use of the abundance of publicly-available knowledge and the potential for networking and collaboration among researchers (p. 44) the user innovation model adds the prospect of going beyond the experience and creativity of professionals by involving end users throughout the development process, treating them as co-developers rather than just as clients or passive test subjects (Curley and Salmelin, 2013). In this context, a Living Lab can initially be defined as an innovation ecosystem and collaborative process based on three features: user involvement in the innovation process, experimentation in real-life settings, and the gathering of stakeholders in "public-private-people partnerships" (Dubé et al., 2014). The European Network of Living Labs (ENoLL) distinguishes between "knowledge transfer between organizations" at the macro level and "user innovation and involvement" at the micro level, holding both to be critical to the Living Lab. (GarciaRobles et al., 2015) From these diverse origins, a pattern emerges centered at once on a strong focus on information and communications technology and on "experimenting and prototyping in real world settings with real people" (EU Commission 2015: 4)

The European Union adapted elements of both the endogenous development and the open innovation models as elements of its response to what it labeled the "European Paradox" Europe's relative inability to transform scientific excellence into marketable innovation. (EU Commission, 1995; EU Presidency, 2000; EU Presidency 2006) This effort has given rise since 2010 to the "innovation union" project as part of Horizon 2020. The central motivation for this effort is expressed directly in a 2017 Commission report:

Innovation means prosperity. It drives productivity and economic growth, creates opportunities for new and better jobs, enables social mobility and is instrumental in responding to global societal challenges. In times of profound technological and societal transformation, the competitiveness of the European economy and the well-being of European citizens dependmore than ever - on the ability of our businesses to develop and successfully commercialize innovative solutions. Innovation increases efficiency, boosts company productivity and provides huge benefits to consumers. (EU Commission, 2017: 4)

With this statement, we are still in the world of economic innovation, although clear links are made to social goals such as better jobs, social mobility, or well-being. The next analytical challenge is to follow the translation of elements taken from these economic policies into the realm of social policy. 


\section{Policy in (Cross-Sectoral) Translation}

When it comes to describing what it is - rather than simply contrasting it with older approaches - characterizations of SI focus as much (or more) in process as on product. (Reynolds et al., 2016 : 4) It is here that the contribution of, the open / user innovation model becomes apparent. Statements such as the following, are drawn directly from the vocabulary of user innovation.

By engaging a social actor, the quadruple helix model arguably proposes a better answer to societal challenges. (OECD, 17)

The imported element, however, is put to a distinct and novel use: the "fourth" helix here is defined as "civil society," whereas in the technology sector the new actor is typically characterized as the "user" or more directly the "client" of a potential new good or service. When the OECD calls for "smart, sustainable, inclusive ..." innovation, its goal is clearly social. The purpose is to "help address pressing social and global challenges, including demographic shifts, resource scarcity and the climate change." (OECD, 11) This is in clear distinction with Chesborough's model of open innovation, where innovation was indeed a goal unto itself, and with the EU's answer to the "European paradox," in which markets and profits (not social goals and global challenges) were the focus. This is a good example of translation across sectors: we see the imported element (open innovation) in its new context (social challenges).

The vocabulary and concepts of endogenous development, likewise, can be found in numerous discussions of SI. The endogenous development model and the EU's integrated approach that followed from it share with the concepts of open and user innovation the starting point that the market must be improved and if need be corrected, but not eliminated altogether, in order for socially optimal solutions to emerge. Central to this improvement and correction of the market is the involvement of national and European actors alongside local stakeholders. Much more than the open or user innovation model, thus, the EU's approach stressed vertical integration in addition to horizontal networking. This legacy is still evident in the Commission's approach to SI. The Program for Employment and Social Innovation (EaSI) is conceived in the context of a "common strategic framework" that also includes all of the EU's Strategic and Investment Funds. (DG REGIO, 2014: 30) Logically, this common framework stresses the achievement of social goals through economic means. Whichever the direction, however, translation necessarily involves transformation. Returning to our conceptual starting point, we can now see how, in this case, imported ideas and preexisting practices come together to form innovative instruments. (Campbell, 2004: 70)

\section{Social Innovation in Turkey: Translation Across National Borders}

Understanding the dynamic of cross-sectoral translation that gave rise to the SI model is only the first step in understanding its implementation in practice. A necessary complement is the analysis of a second phase of translation, across geographical space. As suggested in the introduction to this article, we suggest that understanding translation in this first case helps to appreciate its impact in the second. In cross-national just as in crosssectoral translation, SI is not introduced into an empty field: pre-existing national social policies, as well as cultural and economic situations must be taken into consideration. 
Once again, translation can be understood as the combination of imported and indigenous elements, both of which contribute to the ultimate outcome.

One attempt to define this dimension comes from the OECD (2016: 26,27), which begins from the observation that "the consensus among academics and research practitioners is that social innovation systems differ from one country to another." To capture these differences, the authors propose a three-fold typology of social innovation systems that distinguishes "Anglo-Saxon," "Continental," and "East European" variants. With respect to the prospects for social innovation, the "Anglo-Saxon" situation is characterized by a leading role for "social enterprise," private sector firms that combine profit seeking with social initiatives, often in cooperation with non-profit foundations. The Continental European model gives a leading role to government institutions and the EU. The "East European" model, finally, is characterized by low trust in state institutions and a correspondingly larger role for civil society actors such as foundations and NGOs. Typologies such as this, of course are meant to be at best indicative. Within this "continental" model, a distinction is made between "northern" and "southern" variants in which the latter, typified by Mediterranean sates, are distinguished by a relatively low level of social transfers partly balanced by family networks. (OECD, 2016: 27) As we turn to the Turkish case, we can see both the usefulness and the limits of this exercise in typology. The translation of SI into Turkish social reality, should be expected to yield a distinct pattern of its own. Two examples of contemporary SI initiatives can help us to better understand the outlines of this pattern, as well as illustrating the interaction of local context and imported instrument in the dynamic of cross-border translation.

\section{The Turkish Social Policy Context and the Başakşehir Destek Kart}

Turkey remains well below the OECD average both for total social spending and for the share of spending going to the lowest income citizens. However, Turkey's public spending on welfare has generally been increasing since 1980. (OECD, 2018) Additional elements of the Turkish situation suggest areas of overlap with both the 'south European' and the 'east European' components of the OECD's typology of social innovation systems.:

- as in the 'south European' model, large (unpaid) role for family members (generally women) as social caregivers (Bugra and Keyder, 2006: 212)

- as in the 'east European' model widespread skepticism of state intervention (Bugra and Keyder, 2006: 216)

Turkey's official social welfare system was long characterized by a bifurcated structure, in which salaried employees were covered by a Bismarkian system of health and pension benefits, while self-employed persons, unpaid family workers, and all participants in the informal sector remained outside of the system. (Bugra and Candaş, 2011) Important reforms were made to these policies after 2010. Agartan (2015: 989) characterizes the content of the reforms as "a social neoliberal approach," combining "encouragement of private provision with increased state regulation." This builds on a typically Turkish tendency of mixing public and private financing of welfare programs, as exemplified by the "Fund for the Encouragement of Social Cooperation and Solidarity" created in 1986 and significantly expanded after 2001 . 
From the perspective of an idealized version of the European welfare state, this situation might seem globally negative because of its dependence on family or on private charity for public service, going against an emphasis on the public monopoly of support. They are more compatible, however, with the development of social innovation as describe above. While it does not seek to eliminate the state's role, a central element of $\mathrm{SI}$ is the encouragement of a collaborative and networked approached linking public and private actors. An initial observation, thus, is that while SI initiatives in Western Europe are aimed principally at correcting perceived weaknesses of mature welfare states, the relatively late and still uneven development of Turkish social policy creates opportunities for SI initiatives to be applied to policy areas or populations that up until now were largely outside the scope of official social policy, such as the urban poor or newly-arrived refugees. The post-2002 reforms suggest a broader context open to private initiative and competition, which are a central feature of SI. Finally, the practice of including private funding as part of the budget of public social policies, although it has been criticized as opaque, can also be seen as a contextual element favorable to SI's focus on public-private partnerships. The Destek Kart (support card), to which we turn for our first example, illustrates a number of these features.

Created by the municipal government of Başakşehir, in the western suburbs of Istanbul, the Destek Kart is a debit card, regularly topped up, that allows holders to make certain purchases in designated local shops. As originally conceived in 2010 the use of the card was limited to food purchases. The move to smart card technology in 2011 made it possible to expand uses to include purchase of defined quantities of clothing and school supplies. The card is limited to families, and is entrusted almost exclusively to women; only when there is no healthy woman in a household is it conceivable to give the card to a man. In every case, the card is personal and bears the user's picture. As a policy put in place by the district municipality, only district residents are eligible. The card is recharged in increments of 200 Turkish Lira (TL) ${ }^{2}$ with an additional 5 TL added for each child between 6 and 18. In the case where one of the parents is deceased, an additional 5TL is added per child. The frequency with which the card is recharged depends on per capita family income.

In the context both of cross-sectoral and of cross-national translation, this initiative is interesting for a number of reasons. It illustrates both the strengthening of certain aspects of the imported instrument and the transformation of other aspects. To begin with the second of these, it is notable that the Destek Kart was one of the central elements put forward in Başakşehir's successful 2012 application for inclusion in the European Network of Living Labs (ENoLL). The resulting structure, Başakşehir Living Lab (BLL) is focused on communication technologies and product and service design. To a considerable extent the technical aspects of the Destek Kart were seen in this context as an end unto itself: a proof of technological modernity destined to impress and attract investors. This is particularly true with respect to the use of 'smart card' technology, which was not part of the original design but was added at the time of the district's application to ENoLL. The broader purpose, according to one official interviewed, was to contribute

2 As of 2014, when field research for this part of the project was completed, this sum was the equivalent of approximately 66 Euro or 75 USD. 
to establishing the image of Başakşehir both as socially progressive and as "a district of exemplary modernity." ${ }^{.3}$ Despite the link with the Living Lab movement, however, the vision of the various partners represented here is closer to that of the OECD, as cited above, than to that of the theorists of user integration. Users of the Destek Kart were in not actively involved in its conception. Civil society and private sector participation, on the other hand, is evident.

Indeed, this initiative implements a number of the principles of social innovation. Structured around close ties with private stakeholders and entrepreneurs, it seeks a social goal without excluding the economic dimension and the participation of forprofit organizations. The program is financed by a combination of public funds from the municipal budget and contributions from foundations and businesses. By largely replacing the former practice of in-kind distribution of goods to needy families, it integrates them more closely into the local market, instead of trying to insulate them from it, while also creating indirect benefits for local businesses by increasing effective demand for their products. The involvement of "civil society" in its various forms, rather than active participation of users in program design, is central to the design and functioning of the Destek Kart. Surprising from the perspective of "user innovation" this is understandable when put in the perspective of the translation of this instrument into the pre-existing context of Turkish social policy, with its central place for civil society organizations as partners in public social action.

\section{The Turkish Migration Policy Context and the Red Crescent Debit Card}

A very different context for income support through smart card technology is presented by the massive influx into Turkey of persons displaced by the Syrian civil war. The context into which the Red Crescent's initiative has been translated is marked by the evolution of welfare state institutions discussed above, but also by a significant reform of migration and asylum policy, which has sought to bring Turkish law and practices into closer alignment with those of the European Union. A critical step in this reform was outlined in the 2003 National Program for the Adoption of the EU Acquis Communautaires, which was followed in 2005 by the National Action Plan for Adoption of the EU Acquis in the Field of Asylum and Immigration. Implementing the principles contained in the National Action Plan took almost a decade. In 2014, the first Turkish law to explicitly deal with the question of asylum defined temporary protection status (TPS), as a status that "may be provided to foreigners, who were forced to leave their countries and are unable to return to the countries they left and have arrived at or crossed the borders of Turkey in a mass influx seeking immediate and temporary protection." Unlike the first three, this status can be applied collectively to a group of persons displaced suddenly due to the hardship in the departure countries such as: war, natural disasters etc. Thus, TPS can be accorded in conditions in which individual assessment of asylum application cannot be carried out. A model for this status was the policy applied by some EU member states to persons fleeing the Yugoslavian wars of the 1990s. (Ministry of Family and Social Policies, 2015: 17). In Turkish law, this represents a shift away from prior policy designating those who did not qualify for refugee status simply as "guests," which was the designation early arrivals from Syria received. (Killberg, 2014).

3 Author interview, 12 February 2014 - Director of information management, Başakşehir. 
The massive arrival of persons displaced by the Syrian conflict after 2011 prompted further policy action. The scope and benefits of Turkey's temporary protection status were expanded and made more explicit by the regulations published in October 2014 granting access to a broad set of rights, including health and social assistance. (İçduygu and Millet, 2016: 4). Contributing to the resources making this expansion of social rights possible was financial assistance from the European Union coordinated through the EU Regional Trust Fund in response to the Syrian Crisis (Madad Fund) since 2014 and, more recently, with particular respect to Turkey, through the 2016 EU Facility for Refugees in Turkey. The latter was conditioned, however, on Turkish compliance with the 2015 EU-Turkey Joint Action Plan on migration, through which Turkey committed itself to preventing undocumented migrants on Turkish soil from crossing into the EU. It is into this complex legal, humanitarian, and diplomatic context that the Red Crescent debit card was introduced.

This initiative follows from a partnership between the European Union and Turkey, implemented by the World Food Program in collaboration with the Turkish Red Crescent. It is built upon the existing architecture and expertise of the Turkish Ministry of Family and Social Policy (MoFSP) under the coordination of the Turkish National Disaster Management Authority (AFAD). This multi-purpose card can be used in shops just like other debit cards in order to purchase the most basic needs in terms of food, shelter, water and sanitation in local markets, The debit cards now enables refugees to shop via Turkish Halkbank POS machines and withdraw money from ATMs. (WFP Turkey, 2017) This card is given mostly to the women, handicapped persons, and children. It represents 120 million Euro in spending in the Turkish domestic market. In the EU documents, some features of the card are underscored such as: booster of local businesses, costeffectiveness and empowerment of refugees by giving freedom of choice to "manage their families' priorities with a degree of independence and allows them to stretch their budgets further". (WFP Turkey, 2017)

As of 2017, about 1 million and 60 thousand Syrians (Bilgehan, 2017) living in cities, were eligible to be supported financially each at $\$ 28.5$ monthly with the Red Crescent debit card. Globally, this represents a total budget of $\$ 375$ million ( $€ 348$ million) for refugees in Turkey. This is a part of the Emergency Social Safety Net (ESSN) humanitarian assistance program, which is financed by the European Union and its Member States under the Facility for Refugees in Turkey. (EU Commission, 2016a) Analyzing this initiative as an example of cross-border policy translation builds on all of the elements presented so far, from the evolving content of the concept of social innovation to the impact of translations both across sectoral and across national borders.

As with the Başakşehir Destek Kart, but on a much larger scale, the use of technology is only the most visible "innovation" embodied in this policy, which makes it possible to provide material support to displaced persons without needing to concentrate them into one place. References to freedom of choice and budget management place this initiative squarely in the liberal-inspired philosophy of individual empowerment discussed, above. Considering the initiative in its broader context, meanwhile, we can also see that the Red Crescent Card is made possible by and furthers the logic of the EU-Turkey agreements for the management of displaced persons by contributing to their integration in the Turkish economy. 


\section{Policy in (Cross-National) Translation}

Beyond the variety of scale, purpose, and mechanism, these diverse initiatives have a number of features in common. Most obvious is the central role played by innovative technologies such as smart cards. Throughout the world, smartcards are increasingly being used for delivery of social welfare programs. Examples range from the Supplemental Nutrition Assistance Program (SNAP) in the USA to the UN's World Food Program. Smartcards are used in Indonesia for payments related to family and welfare policies through the Smart Indonesia Cards and in India for beneficiaries of employment (NREGS) and pension (SSP) programs. This type of card is used in Rwandan refugee camps, and multiple purpose debit cards, which can be used by different agencies, are used in Kenya, Jordan, and Lebanon. (Republic of Rwanda, 2016) Although the targeted users and the benefits distributed vary widely, the move to smartcards is generally justified in terms of cost-effectiveness, time saving, and accountability; they are held to be less prone to abuse and corruption.

From the perspective of this article, the Turkish examples explored here underscore the dynamic of translation at the heart of the SI model. Each in its own way embodies the application to social purposes of innovations originating in the world of Information and Communication Technology, but perhaps more importantly the market turn in social policy and the blurring of the line between public and private.

Both initiatives seek to transform low-income economies (or, in the case of displaced persons, economies in which there may be no income at all) in market-compatible ways. Unlike in-kind distribution, which supplants the market by placing certain basic necessities outside it, these initiatives, by transferring purchasing power rather than goods, encourage the integration of their holders into the market system by creating economic space in which they can face risk. Monetization of social material distribution also encourages integration into local market economy by creating empowerment at the individual level both for aid recipients and for local businesses. Far from being threatened by unfair competition from freely distributed aid, the latter are put in a position to benefit from the aid in the form of new paying customers.

A central element in each case is the systematic blurring of the lines between public and private: between the state, businesses, civil society, and banking systems and payment technology providers. Involvement of banking system and payment technologies provides larger access to local economy for aid recipients and allows easy access to payment networks for providers. Also blurred are the lines between the state and civil society organizations such as the Red Crescent or the charitable foundations which make financial contributions to local-level social policy initiatives.

Both initiatives, finally, translate an instrument that is gaining broad use in a variety of international contexts into specific national and local contexts. The Red Crescent card enables Turkish authorities and their NGO partners to offer assistance to displaced persons outside the confines of camps, which is a central element of the contemporary situation. This, in turn, gives substance to the 2014 regulation, cited above, that guarantees the eligibility of persons under TPS to social assistance. The Başakşehir Destek Kart, for its part, plays a role in improving the efficiency of local social assistance, but also as a technology demonstration project for a municipal government eager to attract attention and investment - by putting forward its "exemplary modernity". 


\section{Conclusion: Policy Translation as a Research Agenda}

In a broader analytical context, the conceptual elements presented here point the way both to a fruitful agenda for research and to important considerations for how the findings of that research should be considered. The centrality of translation as an explanatory dynamic and its analytic superiority to competing notions such as policy transfer, emulation, or learning is doubly apparent in the case of SI since it allows us to consider not only how the approach crosses national borders but also how it has itself been constructed by repeated translation across conceptual borders. This allows us to avoid the conceptual traps both of teleology, treating all change as necessarily converging to a predetermined model, and of reification, treating what is properly a complex abstract notion as if it were a simple object.

Social Innovation, as we have seen here, is best understood as the recombination of policy elements whose origins are varied, including concepts and instruments with origins in economic fields such as open innovation in ITC and territorial endogenous development. To this, it adds a critique of the top-down welfare state and the monopoly of national-level governments as service providers. It emphasizes instead cooperative endeavors among public agencies, social society organizations and economic firms at all levels, with a particular emphasis on the involvement of local actors. A unifying theme, finally, is the determination to empower individuals within the market rather than protecting them from it.

The resulting instruments are far from uniform. Rather they tend to emphasize one or the other of these origins. As they are implemented in a variety of national and social settings, they will also incorporate elements of these different contexts, further enriching the original model and adapting to different local needs and conditions. To return to the examples introduced in the introduction to this paper, user empowerment means one thing in the context of Living Labs and a very different one for the Red Crescent debit cards. The tradition of private-sector led social enterprise may be dominant in some cases; while partnership between the state and NGOs are more evident in others. Far from calling into question the usefulness of social innovation both as a policy approach and an analytical category, this diversity provides an accurate reflection of SI's origins and development. It is through continued comparative analysis that we can best hope to add to the understanding of this new generation of social policy instruments.

\section{References}

Ağartan, T. I. (2015). Explaining large-scale policy change in the Turkish healthcare system: Ideas, institutions, and political actors. Journal of Health Politics, Policy and Law, 40(5), 971-999.

Almirall, E., Lee, M., \& Wareham, J. (2012). Mapping Living Labs in the landscape of innovation methodologies. Technology Innovation Management Review., 12-18. https://timreview.ca/article/603

Angelini et al. (2016). Senior Living Lab: An Ecological Approach to Foster Social Innovation in an Ageing Society. Future Internet, 8(4): 50, https://doi.org/10.3390/fi8040050

Aydin, U. and Kirişçi K. (2013). With or without the EU: Europeanization of asylum and competition policies in Turkey. South European Society and Politics, 18(3), pp. 375-395.

Ark, C. \& Smyrl, M. (2017). Innovation Ouverte et 'Living Labs': Production et Traduction d'un Modèle Européen. Revue Française d'Administration Publique, (161), 89-102.

Ark-Yıldırım, C. (2018). Cash Assistance by Smart Card: from multiple functions to multiple legitimacies of a municipal social policy instrument. Turkish Studies, DOI: 10.1080/14683849.2018.1454836.

Ayres, C. (1944 - reprinted 1975). The Theory of Economic Progress. Kalamazoo, MI: New Issues Press, Western Michigan University. 
Bache, I. and Jordan, A. (2006). Europeanization and domestic change. In The Europeanization of British politics, (Ed.) I. Bache and A. Jordan, 17-36. Basingstoke: Palgrave Macmillan.

Behrens, P. and Smyrl, M. (1999). A conflict of rationalities: EU regional policy and the single market. Journal of European Public Policy, 6(3) , 419-435.

Bilgehan, Z., (2017, October,14) Mülteci Hesab1, Hürriyet, Retrieved from http://www.hurriyet.com.tr/amp/ multeci-hesabi-40644078

Buğra A., \& Candaş A. (2011), change and continuity under an eclectic social security regime: The case of Turkey. Middle Eastern Studies, 47(3), 515-528.

Buğra A., \& Keyder Ç., (2006). The turkish welfare regime in transformation. Journal of European Social Policy, 16(3), 211-228.

Campbell, J. (2004). Institutional Change and Globalization. Princeton, NJ : Princeton University Press.

Chalmers, D. (2012). Social innovation: An exploration of the barriers faced by innovating organizations in the social economy. Local economy, 28(1), 17-34

Chesbrough, H. (2003). Open Innovation: The New Imperative for Creating and Profiting from Technology. Boston: Harvard Business School Press.

Curley, M., \& Salmelin, B. (2013). Open Innovation 2.0: a New Paradigm. Brussels: European Commission.

Davies, A., Caulier-Grice, J. \& Norman, W. (2012). Introduction to Innovation: A literature review of the methods and policies for innovation', a deliverable of the project: The theoretical, empirical and policy foundations for building social innovation in Europe' (TEPSIE), European Commission - 7th Framework Program. Brussels: European Commission, DG Research.

De Kort et al. (2015). Organization of labor, quality of work and relational conditions in Care Living Labs. Paper presented to the Open Living Lab Days conference, Istanbul.

DG REGIO (Directorate General for Regional and Urban Policy). (2014). Enabling Synergies Between European Structural and Investment Funds. Brussels: European Commission.

DG CONNECT (Directorate General for Communications Networks, Content and Technology). (2014). Open Innovation Yearbook, 2014. Brussels: European Commission.

DG CONNECT (Directorate General for Communications Networks, Content and Technology). (2015). Open Innovation Yearbook, 2015. Brussels: European Commission.

DG INFSO. (Directorate General for Information Society and Media). (2009). Living Labs for User-Driven Open Innovation: An Overview of the Living Labs" Methodology, Activities and Achievements. Brussels: European Commission.

Dubé, P., Sarrailh, J., Billebaud, C., Grillet, C., Zingraff, V. and Kostecki, I. (2014). Le Livre Blanc des Living Labs (1st ed.). Montréal : Umvelt.

Duman Selman, Y. (2011). Regional Innovation Policy: An Analysis of Turkey’s Aegean, Marmara, East Anatolia and Southeast Anatolia Regions, Alternatives: Turkish Journal Of International Relations, Cilt: 10, Sayl :1, ss: 37-57.

Dutilleul, B. et ali. (2010). Unpacking European Living Labs : Analyzing Innovation's Social Dimensions. Central European Journal of Public Policy 4(1), 60-85.

EU Commission. (1995). Green Paper on Innovation (Com 95-688). Brussels: European Commission.

EU Commission. (2013). Guide to Social Innovation. Brussels: European Commission.

EU Commission (2015) Open Innovation 2.0 Yearbook : 2015. Brussels : European Commission.

EU Commission (2016a) Fact Sheet, Managing The Refugee Crises, EU-Turkey Statement, Brussels, 4 October 2016, Retrieved, May 2018 from: http://europa.eu/rapid/press-release MEMO-16-3218 en.htm

EU Commission (2016b) Fact Sheet, Brussels 8 September 2016, Retrieved, May 2018 from: http://europa.eu/ rapid/press-release_MEMO-16-2989_en.htm

EU Presidency. (2000). Presidency Conclusions: Lisbon European Council 23 and 24 March 2000.

EU Presidency. (2006). Networked Business and Government: Something Real for the Lisbon Strategy. 20 November 2006.

Esping-Andersen,, G. (1990). The Three Worlds of Welfare Capitalism. Cambridge, UK: Polity Press.

Evans, P. \& Hall R., (2015). Girls Making History: Summary report communities culture funded research pilot. Paper presented to the Open Living Lab Days conference, Istanbul.

Franz, Y. (2015). Designing Social Living Labs in Urban Research. Technical Innovation Management Review. 2012. Special Issue on Living Labs (September 2012).

Garcia-Robles, A. et ali. (2015). Introducing ENoLL and its Living Lab Community. Brussels: ENoLL.

Hall, P. and Soskice, D. (2001). Varieties of Capitalism: The Institutional Foundations of Comparative Advantage. Oxford: Oxford University Press.

Hassenteufel, P. and De Maillard, J. (2013). Convergence, transfert et traduction: Les apports de la comparaison internationale. Gouvernement et Action Publique 3: 3, pp. 377-393.

Heclo, H. (1974). Modern Social Politics in Britain and Sweden: From Relief to Income Maintenance. New Haven and London: Yale University Press

Hochgerner, J. (2011). The analysis of social innovations as social practice. In: bridges vol. 30, July 2011, http:// ostaustria.org/325-categories-all/magazine/volume-30-july-20-2011/feature-articles/5708-the-analysis-ofsocial-innovations-as-social-practice. 
Holzinger, K. and Knill, C. (2005). Causes and conditions of cross-national policy convergence. Journal of European Public Policy 12: 5, pp. 775-796.

Kingdom, J. (1984). Agendas, Alternatives and Public Policy. New York: Harper Collins Publishers.

Le Grand, Julian. (2003). Motivation, Agency and Public Policy. Oxford, UK: Oxford University Press.

Leys et al. (2015). Care Living Lab Flanders: Social and Open Innovation. Paper presented to the Open Living Lab Days conference, Istanbul.

Mulgan, G., Tucker, S., Ali, R., Sanders, B. (2007). Social Innovation: What It Is, Why It Matters and How It Can Be Accelerated, Working Paper, Skoll Centre for Social Entrepreneurship, Oxford Saïd Business School

Morel, N., Palier, B., Palme, J., eds. (2011). Toward a Social Investment Welfare State? Ideas, Policies and Challenges. Bristol, UK: Bristol University Press.

Myrdal, G. (1957). Economic Theory and Underdeveloped Regions. London: G. Duckworth.

OECD. (2012) Science, Technology And Industry Outlook, http:/www.oecd.org/turkey/sti-outlook-2012turkey.pdf

OECD. (2016). Social Innovation Policy Framework for Croatia. Paris: OECD South East Europe Regional Programme.

OECD (2018), Social spending (indicator). doi: 10.1787/7497563b-en (Accessed on 22 May 2018). https:// stats.oecd.org/Index.aspx?DataSetCode=SOCX_AGG;

Phills, J. A., Deiglmeier K., Miller, D. T., (2008). Rediscovering Social Innovation. Stanford Social Innovation Review. 6 (4), 37-43.

Republic of Rwanda - Minsistry in Charge of Emergency Management. (2016). Smart Card Use for Refugees Launched. Retrieved November 2018 from:

http://midimar.gov.rw/index.php?id=45\&tx_ttnews\%5Btt_news\%5D=112\&cHash $=87 \mathrm{ba} 18759 \mathrm{c} 3 \mathrm{~cd} 3 \mathrm{a} 8 \mathrm{e} 181 \mathrm{a} 06 \mathrm{de} 5 \mathrm{~cd} 47 \mathrm{ff}$

Reynolds, S., Madeleine G., \& Heales, C. (2016). Social Innovation Policy in Europe: where next? SI Policy in Europe. Social Innovation Community: an H2020 research and innovation Project under grant agreement $\mathrm{n}^{\circ}: 693883$.

Saurruger, S. and Yves S. (2006). L'Européanisation comme procéssus de transfert de politique publique. Reveu Internationale de Politique Comparée, 13(2), pp. 179-211.

Schuurman, D. (2015). Bridging the Gap Between Open and User Innovation? PhD Dissertation presented jointly to the University of Ghent and the Free University of Brussels.

Schuurman D. et al. (2015). Living Labs: A Systematic Literature Review. Paper presented to the Open Living Lab Days conference, Istanbul.

Smyrl, M. (2008). French Regional Elites and EC Regional Development Policy. In Smyrl, Marc \& William Genieys. Elites, Ideas, and the Evolution of Public Policy. Palgrave-MacMillan.

Smyrl, M. (2014). Beyond Interests and Institutions: US Health Policy and the Surprising Silence of Big Business. Journal of Health Politics, Policy, and Law 39: 1, pp, 5-34.

TEPSIE (Theoretical, Empirical and Policy Foundations for Social Innovation in Europe). (2012). An Introduction to Innovation Studies for Social Innovators. (Deliverable 1.3 of the FP7 project TEPSIE)

World Food Program (WFP) - Turkey. (2017). The Emergency Social Safety Net (ESSN) and the Grand Bargain, Retrieved, May 2018 from: https://docs.wfp.org/api/documents/WFP-0000021046/download/

Yilmaz, G. (2017). It is voluntary transfer! Exploring Healthcare Reforms in Turkey. Turkish Studies 18: 4, pp. 665-687.

Zito, A. ed. (2013) Learning and Governance in the EU Policy Making Process. London and New York: Routlage. 
